\title{
Accumulation of organic matter within a muddy carpet created by the Asian date mussel, Arcuatula senhousia, on the Midori River tidal flats, Japan
}

\author{
Risa TAKenaKa ${ }^{1, *}$, TOMOHIRo Komorita ${ }^{2} \&$ Hiroaki Tsutsumi $^{2}$ \\ ${ }^{1}$ Graduate School of Environmental and Symbiotic Sciences, Prefectural University of Kumamoto, 3-1-100 Tsukide, Kumamoto \\ 862-8502, Japan \\ ${ }^{2}$ Faculty of Environmental and Symbiotic Sciences, Prefectural University of Kumamoto, 3-1-100 Tsukide, Kumamoto 862- \\ 8502, Japan
}

Received 6 October 2017; Accepted 28 November 2017 Responsible Editor: Shigeaki Kojima

\begin{abstract}
The Asian date mussel (Arcuatula senhousia) dominates macrobenthic communities on the Midori River tidal flats on the island of Kyushu, the southernmost of Japan's main islands. They form dense patches and create mats on the sediment surface. We conducted field surveys between May 2014 and April 2015 to assess the vertical distribution of sedimentary conditions (depth $0-12 \mathrm{~cm}$ ) and determined the seasonal variation in density, biomass, and secondary production of A. senhousia on the tidal flats. Arcuatula senhousia density and biomass reached a maximum of 80,800 individuals per square meter (ind. $\mathrm{m}^{-2}$ ) in September and 4,988 g wet weight (WW) $\mathrm{m}^{-2}$ in August, respectively. We defined a sediment layer with $>10 \mathrm{mg}$ dry weight (DW) of byssus as the byssus layer. From May to November, the integrated standing stock of sedimentary nitrogen $(\mathrm{N})$ within the byssus layer derived from A. senhousia (150.7 $\mathrm{g} \mathrm{N} \mathrm{m}^{-2} 7$ months $^{-1}$ ) was as high as the secondary production of $A$. senhousia $\left(161.8 \mathrm{~g} \mathrm{~N} \mathrm{~m}^{-2}\right.$ year $\left.^{-1}\right)$. Thus, this study clearly indicates that accumulated sedimentary nitrogen within the byssus layer plays a considerable role in nutrient cycling in the Midori River tidal flats.
\end{abstract}

Key words: Arcuatula senhousia, Asian date mussel, byssus, ecosystem engineer

\section{Introduction}

Suspension-feeding bivalves are key players in organic nutrient cycling in coastal regions (Dame 2011). They consume a substantial amount of organic matter that is photosynthetically produced by primary producers, such as phytoplankton; excrete inorganic nutrients and feces containing undigested organic matter; and accelerate the deposition of organic matter onto the sea floor. For example, Haven \& Morales-Alamo (1972) reported $77 \%-91 \%$ and $4 \%-12 \%$ inorganic matter and organic matter, respectively, in the biodeposits by the eastern oyster (Crassostrea virginica Gmelin), respectively. Jordan \& Valiela (1982) demonstrated that ribbed mussel (Geukensia demissa Dillwyn) populations play a major role in the nitrogen budget by filtrating 1.8 times the particulate nitrogen exported from marshlands and through biodeposition (i.e., deposition of

*Corresponding author: Risa Takenaka; E-mail, g1575001@pu-kuma moto.ac.jp nitrogen as feces and pseudo-feces), and a high level of the nitrogen content is filtered and absorbed by mussels in a salt marsh ecosystem.

In this study, we focused on the impact of mussel (Mytilidae spp.) feeding activities on nutrient cycling in coastal areas. These suspension-feeding bivalves often form dense patches in various coastal environments, and include Mediterranean mussels (Mytilus galloprovincialis Lamarck) in shallow subtidal waters (973-1,695 ind. $\mathrm{m}^{-2}$; Ceccherelli \& Rossi 1984) and blue mussels (M. edulis L.) in tidal flats (1,631 ind. $\mathrm{m}^{-2}$ and 1,208 $\mathrm{g}$ ash-free DW m${ }^{-2}$; Asmus 1987). These dense patches occur when each individual bands with a neighbor by excreting byssus threads onto the sea floor, and these patches often accompany accelerated deposition of fine suspended particles within their assemblage (Morton 1974; Ito \& Kajihara 1981b). The total amount of organic matter stored in their habitat substrate through their direct and/or indirect feeding activities seems to far exceed their own biomass (Miura et al. 2002).

In the Midori River tidal flats in Kumamoto, Kyushu, 
Japan, Asian date mussel (Arcuatula senhousia Benson) predominates. These often form dense patches with other mytilids in various coastal environments, including brackish lagoon $\left(12,453\right.$ ind. $\mathrm{m}^{-2}$; Mistri et al. 2004), muddy tidal flats $\left(8,215\right.$ ind. $\mathrm{m}^{-2}$ and $1,966 \mathrm{gWW} \mathrm{m}^{-2}$; Lim \& Park 1998), and sandy tidal flats (106,880 ind. $\mathrm{m}^{-2}$ and $4,983 \mathrm{gWW} \mathrm{m}^{-2}$; Takenaka et al. 2016). A. senhousia is now well known as an ecosystem engineer (sensu Jones et al. 1994) and an invasive foreign species in countries such as Europe, North America, Australia, and New Zealand (Sousa et al. 2009). Invasion by $A$. senhousia changes the ecosystem dynamics. For example, Crooks (1998) reported an increase in the number of tanaid, gastropod, insect larvae, amphipod, and other benthic species by the new habitat provided by $A$. senhousia. Furthermore, A. senhousia creates wide muddy carpets on the surface of sandy substrates (Tsutsumi et al. 2013).

Arcuatula senhousia populations create a dense carpetlike patch (called a mat), which is attached to the seafloor by their byssus and covers the sediment surface (Morton 1974). The silt-clay content (diameter, $<63 \mu \mathrm{m}$ ) of the mat can increase $11.5 \%$ compared with $<1 \%$ in the outside surrounding area (Tsutsumi et al. 2000). Ito \& Kajihara (1981a) found that sites covered with mats have a mean total sulfide content of $1.1 \mathrm{mg} \mathrm{g}^{-1}$, while those without mats have, $0.4 \mathrm{mg} \mathrm{g}^{-1}$, at most. Thus, we think that these mats are important sink for organic matter. However, no reports have quantified the amount of accumulated organic matter in a mat. For this, information on mat depth is required, but definitions and methods have not been clearly reported. Identifying the sediment layer influenced by $A$. senhousia would be difficult without a sediment tracer.

In this study, we conducted field surveys to describe seasonal fluctuations of population density, biomass, and secondary production of $A$. senhousia populations, their vertical distribution (0-12 cm; density and byssus), and sediment properties (silt-clay content and nitrogen content) on the Midori River tidal flats, Ariake Bay, Kyushu, Japan, between May 2014 and April 2015. The study focused on nitrogen, because phytoplankton production in Ariake
Bay near the Midori River tidal flats is limited by nitrogen (Kawaguchi et al. 2004). We estimated the standing stock of nitrogen of $A$. senhousia as forms of biomass and sedimentary nitrogen within the mat, using the byssus as a tracer. We hypothesize that $A$. senhousia byssus is an important tracer for mat depth. In this study, we aimed to quantify the accumulated organic matter within the mat and to discuss the role of mussel mats in nutrient cycling in the Midori River tidal flats.

\section{Materials and Methods}

\section{Study area}

The Midori River tidal flats are located along the east coast of Ariake Bay on the Japanese island of Kyushu (Fig. 1 ), and they cover an area of approximately 2,200 ha. During the study period, from May 2014 to April 2015, the tidal range at the observatory at the Kumamoto Port was between 78 and $491 \mathrm{~cm}$ (Japan Meteorological Agency 2016). Yamaguchi et al. (2004) reported that the middle-to-lower part of this study area is nearly homogeneous sandy sediment. We set up two stations on the tidal flats: St. F, which was dominated by Arcuatula senhousia and St. R, which had no A. senhousia and was located approximately $1 \mathrm{~km}$ away from St. F.

\section{Sampling procedure}

We conducted 11 field surveys of sedimentary environmental conditions and seasonal variations of $A$. senhousia at the two stations from May 2014 to April 2015. For each field survey, we collected five samples of macrobenthic organisms using a handheld steel core sampler $(10 \times 10 \times 5 \mathrm{~cm})$ and sifted the samples through a $1 \mathrm{~mm}$ mesh sieve. Residues retained on the sieve were added to a plastic bag. To examine the relationship between shell length and DW of $A$. senhousia soft tissue, we collected approximately 40 specimens during each sampling occasion from May 2014 to January 2015 (for a total of 435 individuals). We also collected a few living individuals to

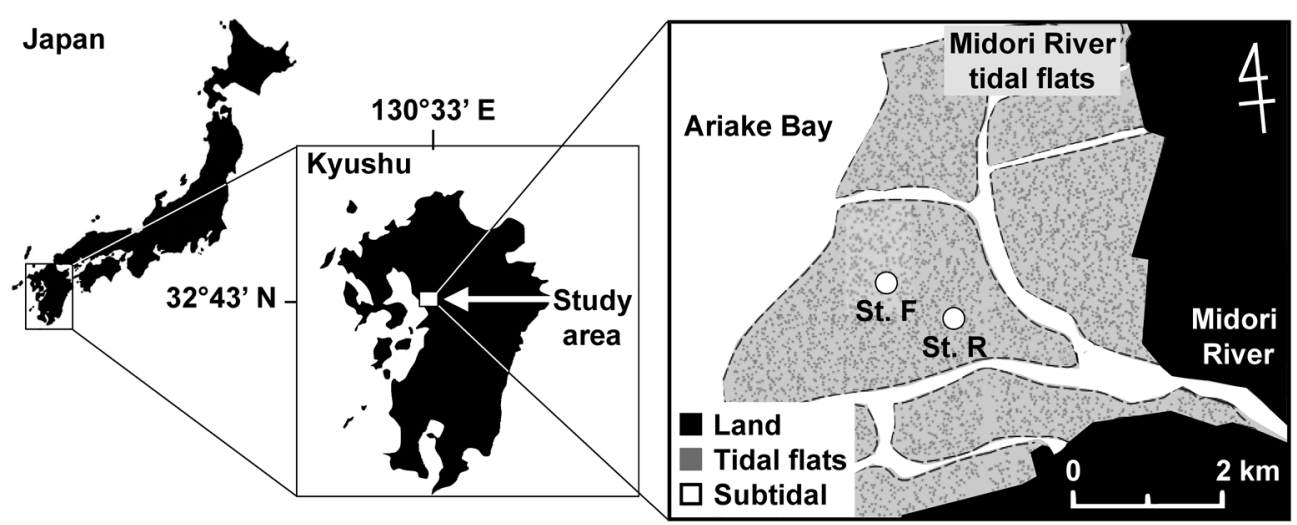

Fig. 1. Geographical location of the Midori River estuary and sampling stations. Black, gray, and white areas represent land, tidal flats, and subtidal area, respectively. 
determine the nitrogen content of the soft tissue.

For the analysis of sedimentary environmental conditions at St. F (measuring vertical distribution of A. senhousia, byssus weight, and silt-clay content and nitrogen content), we collected sediment samples to a depth of $12 \mathrm{~cm}$ using a 7.6-cm-diameter cylindrical core sampler. Sediment samples were cut every $1 \mathrm{~cm}$ down to $6 \mathrm{~cm}$ and then every $2 \mathrm{~cm}$ down to $12 \mathrm{~cm}$. Samples were placed in plastic bags, which were then kept in a cooler. At St. R, we collected sediment samples only in December 2014.

\section{Sample treatment}

The samples of macrobenthic organisms were stained using $10 \%$ formalin and Rose Bengal solution and cleaned using a $1 \mathrm{~mm}$ mesh sieve. The macrobenthic organisms were sorted from the residue, the number of individuals of each species was counted using a stereoscopic microscope, and the wet weight of each species was recorded. Shell length of each $A$. senhousia individual was measured to the nearest $0.01 \mathrm{~mm}$ using a digital caliper, and that of dead shells with both shells present was also measured.

To determine the relationship between shell length and DW of $A$. senhousia soft tissue, living samples were kept in filtered seawater for one day to allow them to pass their stomach contents. Shell length of all specimens was measured, and the soft tissue was removed from the shells and dried at $55^{\circ} \mathrm{C}$ over $24 \mathrm{~h}$ and weighed. The relationship between shell length and dry weight was (all symbols and units are given in Table 1):

$$
D W=1.021 \times 10^{-5} S L^{2.896}, \quad n=435, \quad r^{2}=0.947
$$

where $D W$ is the dry weight of soft tissue $(\mathrm{g})$ and $S L$ is shell length (mm).

To measure the nitrogen content of $A$. senhousia soft tissue, samples were freeze-dried and ground to powder, and nitrogen content was measured using an elemental analyzer (ThermoQuest, NC2500). To estimate the standing stock of nitrogen of the A. senhousia population, the individual dry tissue weight was multiplied by the nitrogen content of the soft tissue $(13.6 \%)$ and species density.

To ascertain the physicochemical properties of the sediment, approximately $10 \mathrm{~g}$ of sediment was packed in a tube and freeze-dried. Arcuatula senhousia byssus threads were removed using tweezers and this byssus-free sediment was ground to a powder, treated with $2 \mathrm{~N} \mathrm{HCl}$ to remove carbonates, and nitrogen content was measured using the elemental analyzer. The removed byssus threads were used to measure the byssus nitrogen content using the same method as that used to measure the nitrogen content of soft tissue.

The wet sieving method was used to determine the siltclay (finer than $63 \mu \mathrm{m}$ in diameter) content of the remaining sediment samples. To determine the vertical distribution of A. senhousia, sediment was sieved through a 1-mm mesh and the byssus threads were collected. Byssus attachments on the $0.5-2.0-\mathrm{mm}$ sieve were removed using tweezers and placed in a beaker with water. These were then placed in a plastic case after the sediment particles were removed, dried at $55^{\circ} \mathrm{C}$ for at least $24 \mathrm{~h}$, and weighed. To estimate the standing stock of byssus nitrogen, byssus DW was multiplied by byssus nitrogen content per unit DW (3.2\%).

\section{Data analysis}

Ito \& Kajihara (1981b) divided muddy mats into two layers: the upper layer inhabited by A. senhousia and the lower layer formed by tangled byssuses, which were named the shell and byssus layers, respectively. In this study, when byssus weight was $>10 \mathrm{mgDW}$ in a layer $\left(45.3 \mathrm{~cm}^{3}\right.$; $3.8 \times 3.8 \times \pi \mathrm{cm}^{2} \times$ depth $1 \mathrm{~cm}$ ) of the sediment samples, that layer was defined as the byssus layer. Layers in which byssus weight was $<10 \mathrm{mgDW}$ were defined as non-byssus layers.

To determine the standing stock of nitrogen within the

Table 1. Definitions of variables and their units used in equations.

\begin{tabular}{|c|c|c|c|}
\hline Variable & Definition & Units & $\begin{array}{c}\text { Equation } \\
\text { number }\end{array}$ \\
\hline$D W$ & Dry weight & g & 1 \\
\hline$S L$ & Shell length of Arcuatula senhousia & $\mathrm{mm}$ & 1 \\
\hline$S$ & Integrated standing stock of nitrogen of the entire byssus layer & $\mathrm{g} \mathrm{N} \mathrm{m}^{-2}$ & 2 \\
\hline$I$ & Number of byssus layers & & 2 \\
\hline$L$ & Nitrogen content of each byssus layer & $\mathrm{g} \mathrm{N} \mathrm{m}^{-2}$ & 2 \\
\hline$A$ & Average nitrogen content of the non-byssus layer (defined as the original nitrogen content of tidal flats) & $\mathrm{g} \mathrm{N} \mathrm{m}^{-2}$ & 2 \\
\hline$M$ & Nitrogen standing stock of $A$. senhousia biomass and sedimentary nitrogen within the byssus layer & $\mathrm{g} \mathrm{N} \mathrm{m}^{-2}$ & 3 \\
\hline$C$ & Change rate of $M$ & $\mathrm{~g} \mathrm{~N} \mathrm{~m}^{-2} \mathrm{~d}^{-1}$ & 3 \\
\hline$P$ & Secondary production of $A$. senhousia population & $\mathrm{g} \mathrm{N} \mathrm{m}^{-2} \mathrm{~d}^{-1}$ & 4 \\
\hline$D$ & Density of $A$. senhousia & ind. $\mathrm{m}^{-2}$ & 4 \\
\hline$B$ & Average weight of soft tissue for all individuals & g N ind. ${ }^{-1}$ & 4 \\
\hline Date & Sampling day & $\mathrm{d}$ & 3,4 \\
\hline$t$ & Number of sample times & & 3,4 \\
\hline
\end{tabular}


byssus layer, sediment samples were analyzed by the following procedure: (1) The substrate was divided into byssus and non-byssus layers. (2) The nitrogen content of each byssus layer and that of each non-byssus layer was measured. (3) The average nitrogen content of the non-byssus layer was calculated for the study period (defined as the original nitrogen content of the tidal flats; $A ; \mathrm{g} \mathrm{N} \mathrm{m}^{-2}$ ). (4) The standing stock of nitrogen of the entire byssus layer $(S)$ for every sampling day was measured using the following equation:

$$
S=\sum_{n=1}^{I}(\operatorname{Ln}-A)
$$

where $S$ is the integrated standing stock of nitrogen of the entire byssus layer $\left(\mathrm{g} \mathrm{N} \mathrm{m}^{-2}\right), L$ is the nitrogen content of each byssus layer $\left(\mathrm{g} \mathrm{N} \mathrm{m}^{-2}\right)$, and $I$ is the number of byssus layers.

The rate of change of nitrogen contents per day was calculated to compare with the excretion of $A$. senhousia. The following equation was used to calculate the change rate $\left(C ; \mathrm{g} \mathrm{N} \mathrm{m}^{-2} \mathrm{~d}^{-1}\right)$ of the nitrogen-based A. senhousia biomass and sedimentary nitrogen within the byssus layer:

$$
C=\left(M_{t+1}-M_{t}\right) /\left(\text { Date }_{t+1}-\text { Date }_{t}\right)
$$

where $M$ is the nitrogen standing stock $\left(\mathrm{g} \mathrm{N} \mathrm{m}^{-2}\right)$, Date is the sampling day, and $t$ is the number of sample times. Secondary production of the A. senhousia population was estimated using the following equation (c.f. Takenaka et al. 2016):

$$
P_{t+1}=\frac{D_{t}+D_{t+1}}{2} \times\left(B_{t+1}-B_{t}\right) /\left(\text { Date }_{t+1}-\text { Date }_{t}\right)
$$

where $P$ is the secondary production of $A$. senhousia population per day $\left(\mathrm{g} \mathrm{N} \mathrm{m}^{-2} \mathrm{~d}^{-1}\right), D$ is density (ind. $\mathrm{m}^{-2}$ ), and $B$ is the average weight of soft tissue for all individuals (g N ind..$^{-1}$ ).

\section{Results}

Figure 2 shows the seasonal variation in (a) population density and (b) biomass, including shell weight, of $\mathrm{Arcu}$ atula senhousia at St. F and St. R. At St. R, A. senhousia individuals were not present throughout the study period, whereas at St. F, the density of $A$. senhousia was 42,000 ind. $\mathrm{m}^{-2}$ in May 2014, and reached a maximum density of 80,800 ind. $\mathrm{m}^{-2}$ in September 2014. The density then drastically decreased to 100 ind. $\mathrm{m}^{-2}$ from October through March 2015. Biomass was $4,988 \mathrm{gWW} \mathrm{m}^{-2}$ in August 2014 and 4,010 $\mathrm{gWW} \mathrm{m}^{-2}$ in November 2014, then gradually decreased until January and suddenly decreased to $<10 \mathrm{gWW} \mathrm{m}^{-2}$ in March 2015.

Figure 3 indicates seasonal variations in the size distribution of $A$. senhousia. The average size of mussels in cohort (1) started at $6.7 \pm 2.3 \mathrm{~mm}$ (mean \pm SD) in May 2014, and 3 months later, it had grown to $15.0 \pm 1.7 \mathrm{~mm}$. The average size of cohort (2) started at $5.0 \pm 1.1 \mathrm{~mm}$ in August
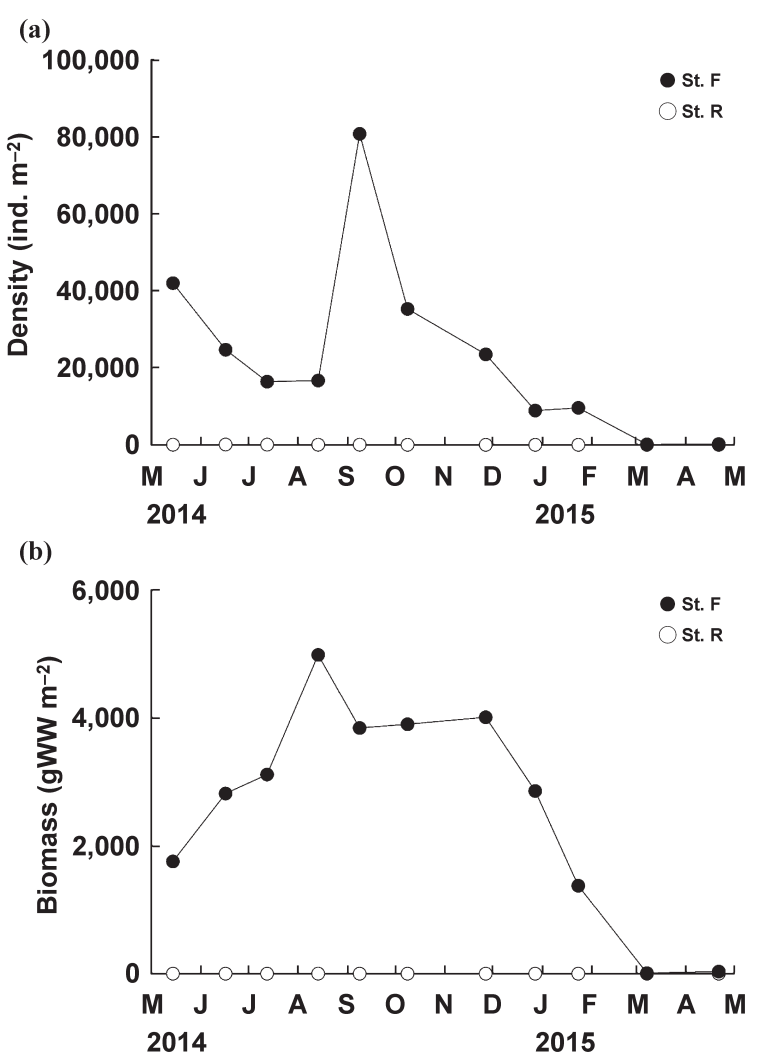

Fig. 2. Seasonal variations of (a) population density and (b) biomass including shell weight of Arcuatula senhousia. $\mathrm{O}$ : St. F, $\bigcirc$ : St. R.

2014 and grew to a maximum of $14.2 \pm 3.4 \mathrm{~mm}$ by January 2015. In the final two months, live individuals almost disappeared and dead shells accounted for most of the collected specimens. Cohort (1) grew approximately $8 \mathrm{~mm}$ on average from spring to summer and cohort (2) grew from $5 \mathrm{~mm}$ to $14 \mathrm{~mm}$ on average from autumn to winter.

Figure 4 shows the vertical distribution of (a) siltclay content and (b) nitrogen content of the sediment at St. F (dominated by A. senhousia) and St. R (absent of A. senhousia) in December 2014. At St. R, the silt-clay content and nitrogen content were $0.9 \% \pm 0.4 \%$ and $0.2 \pm 0.0 \mathrm{mg} \mathrm{N} \mathrm{g}^{-1}$, whereas at St. F, these were $8.5 \% \pm 3.6 \%$ and $0.4 \pm 0.1 \mathrm{mg} \mathrm{N} \mathrm{g}^{-1}$, respectively. During this time, $A$. senhousia maintained both a high density $\left(8,900\right.$ ind. $\left.\mathrm{m}^{-2}\right)$ and biomass $\left(2,857 \mathrm{gWW} \mathrm{m}^{-2}\right.$; Fig. 2).

Figure 5 shows seasonal variations in the vertical distribution of (a) the number of $A$. senhousia in each layer $\left(45.3 \mathrm{~cm}^{3}\right)$, (b) byssus weight in each layer $\left(45.3 \mathrm{~cm}^{3}\right)$, (c) silt-clay content, and (d) nitrogen content of the sediment down to $12 \mathrm{~cm}$ in depth at St. F. The black hatched area on Fig. 5(b-d) indicates the non-byssus layer and demonstrates that most $A$. senhousia individuals were present only on depth $0-2 \mathrm{~cm}$. The highest abundance of $A$. senhousia was observed on the surface layer (depth $0-1 \mathrm{~cm}$ ) in May 2014 [ $n=99$; Fig. 5(a)]. When the density of a quantitative sample was $<100$ ind. $\mathrm{m}^{-2}$ (March and April 2015; 

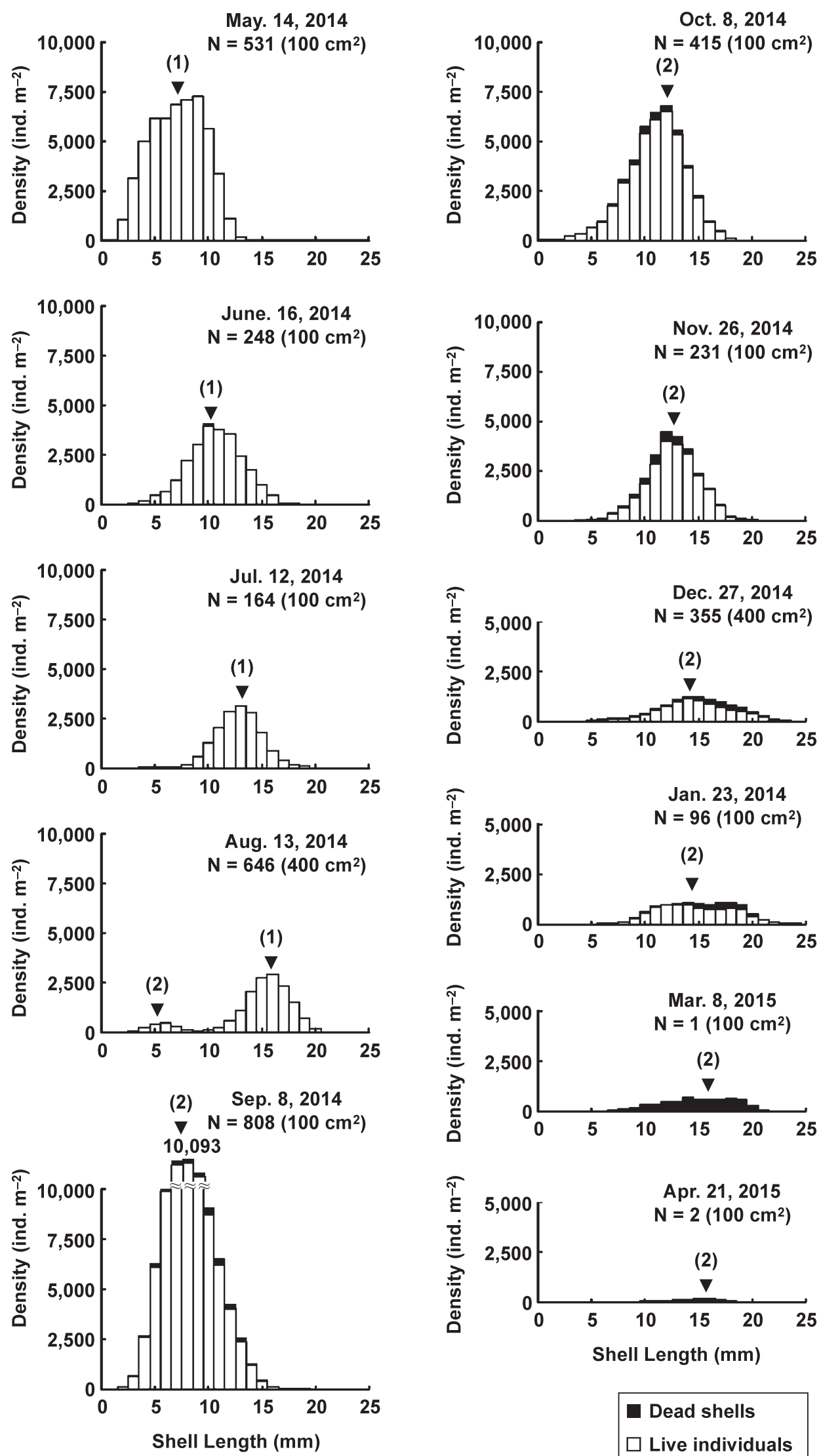

$\square$ Dead shells
$\square$ Live individuals

Fig. 3. Size frequency distribution of Arcuatula senhousia populations at St. F on tidal flats. Open solid: live individuals; closed solid: dead shells. 
(a)

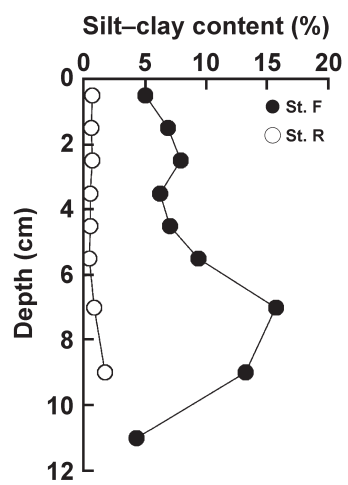

(b)

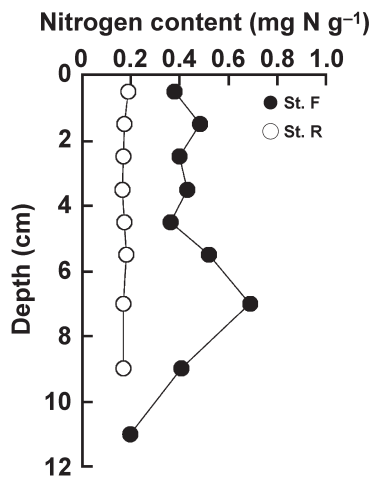

Fig. 4. Vertical distribution of (a) silt-clay content and (b) nitrogen content to a depth of $12 \mathrm{~cm}$. $\mathrm{O}$ : St. F, $\bigcirc$ : St. R in December 2014.

Fig. 2), no mussels were detected from the core sampler. Figure 5(b) indicates that byssus threads were not detected any deeper than approximately $6 \mathrm{~cm}$ from May to August 2014, but extended down to $12 \mathrm{~cm}$ in September and November 2014. The depth of the byssus layer decreased to $8 \mathrm{~cm}$ in January 2015. By April 2015, the boundary of the byssus layer extended $2-8 \mathrm{~cm}$ in depth, and the sediment surface down to $2 \mathrm{~cm}$ was considered the non-byssus layer.

In the byssus layer, the mean silt-clay content was $17.3 \%$ at a depth of 0-2 cm in May 2014 [Fig. 5(c)]. The silt-clay content was $17.4 \% \pm 8.4 \%$ at a depth of $0-12 \mathrm{~cm}$ in September 2014 when the density of $A$. senhousia approached its maximum. The maximum silt-clay content was $56.6 \%$ at a depth of 3-4 cm in October 2014. This content gradually decreased to $6.3 \% \pm 3.3 \%$ at a depth of $2-8 \mathrm{~cm}$ in April 2015. The seasonal variation of nitrogen content was similar to that of the silt-clay content [Fig. 5(d)]. The mean nitrogen content was relatively low at $0.6 \mathrm{mg} \mathrm{N} \mathrm{g}^{-1}$ at a depth of $0-2 \mathrm{~cm}$ in May 2014. When the density of A. senhousia peaked, the nitrogen content also increased to $0.9 \pm 0.3 \mathrm{mg} \mathrm{N} \mathrm{g}^{-1}$ at a depth of $0-12 \mathrm{~cm}$ in September 2014. The highest nitrogen content was $2.6 \mathrm{mg} \mathrm{N} \mathrm{g}^{-1}$ at a depth of 4-5 cm in October 2014. Nitrogen content gradually decreased to $0.4 \pm 0.2 \mathrm{mg} \mathrm{N} \mathrm{g}^{-1}$ at a depth of $2-8 \mathrm{~cm}$ by April 2015.

Seasonal variation in the integrated standing stock of nitrogen of $A$. senhousia, byssus, and sedimentary nitrogen within the byssus layer are shown in Fig. 6(a). The integrated standing stock of sedimentary nitrogen of the byssus layer accounted for $37.3 \%-96.3 \%$ of the total standing stock of nitrogen including $A$. senhousia, byssus, and sedimentary nitrogen, and it increased from $16.1 \mathrm{~g} \mathrm{~N} \mathrm{~m}^{-2}$ in May 2014 to $173.0 \mathrm{~g} \mathrm{~N} \mathrm{~m}^{-2}$ in October 2014 and decreased to $76.8 \mathrm{~g} \mathrm{~N} \mathrm{~m}^{-2}$ in March 2015, which corresponded to the decrease in the density and biomass of $A$. senhousia (Fig. 2). The integrated standing stock of nitrogen of $A$. senhousia reached $45.8 \mathrm{~g} \mathrm{~N} \mathrm{~m}^{-2}$ when biomass was at its highest (August 2014), and sedimentary nitrogen within the byssus layer was of the same order $\left(60.7 \mathrm{~g} \mathrm{~N} \mathrm{~m}^{-2}\right)$. Subsequently,

the integrated standing stock of nitrogen of $A$. senhousia dropped to $0.1 \mathrm{~g} \mathrm{~N} \mathrm{~m}^{-2}$ in March 2015. The integrated standing stock of nitrogen from byssus threads had a minor contribution to the total standing stock, which ranged between 2.4 and $5.4 \mathrm{~g} \mathrm{~N} \mathrm{~m}^{-2}$, except in April 2015. Figure 6(b) shows the rate of change of secondary production and biomass of $A$. senhousia based on nitrogen and sedimentary nitrogen within the byssus layer. The rate of change of sedimentary nitrogen within the byssus layer increased from $0.2 \mathrm{~g} \mathrm{~N} \mathrm{~m}^{-2} \mathrm{~d}^{-1}$ in July to $2.3 \mathrm{~g} \mathrm{~N} \mathrm{~m}^{-2} \mathrm{~d}^{-1}$ in October 2014 and decreased to $-3.8 \mathrm{~g} \mathrm{~N} \mathrm{~m}^{-2} \mathrm{~d}^{-1}$ in December 2014. The total secondary production was $161.8 \mathrm{~g} \mathrm{~N} \mathrm{~m}^{-2}$ year $^{-1}$. From May to November, the total rate of change of sedimentary nitrogen within the byssus layer was $150.7 \mathrm{~g} \mathrm{~N} \mathrm{~m}^{-2} 7$ months $^{-1}$.

\section{Discussion}

In this study, the population density of Arcuatula senhousia was approximately four times higher in September than in August [Fig. 2(a)]. The density growth was assumed to be due to the settlement of a new cohort in August 2014 that had a mean shell length of $5.0 \pm 1.1 \mathrm{~mm}$ (Fig. 3). In the same area, A. senhousia recruitment occurs in the summer (Tsutsumi et al. 2000; Ishii et al. 2001), and it is reasonable to confirm that cohort (2) in this study was the new early summer settlement. As a reason of the density difference between August and September, the new recruitment had occurred at the tidal flats area in summer, but it is thought that we conducted field survey in the minor spot that not have much density in August.

Thereafter, the density of $A$. senhousia declined. Hosozawa et al. (2015) summarized the following causes of A. senhousia mortality: decrease in salinity due to hard precipitating water and flush by typhoon, occurrence of hypoxic water in the summer, predation by ducks from winter to spring, and physical disturbances, such as waves caused by typhoons in Japan. The causes of mortality seemed to be physical forces rather than the predation by birds in this study area (Tsutsumi et al. 2013). In this study, the population most likely declined because of physical disturbance by waves in the winter. It is known that disturbance by wave exposure affects mussels (e.g., Harger 1970; Grant 1977). We divided the study period into a growth period (May-November, 7 months) and a decline period (December-April; 5 months).

The silt-clay content and nitrogen content reached their highest values in the subsurface $(3-5 \mathrm{~cm})$ in October [Fig. $5(c, d)]$. This was because in the summer, cohort (2) created a new mat on the top of the mat that was made by cohort (1), and the excrement and/or silt-clay content and nitrogen content began to accumulate below the new mat. The old mat was pushed down to deeper sediment layers and the soft body of $A$. senhousia remained in the subsurface. Thus, the byssus threads of cohorts (1) and (2) were mixed and could not be separated. 
(a)

Number of Arcuatula senhousia 100 ind.

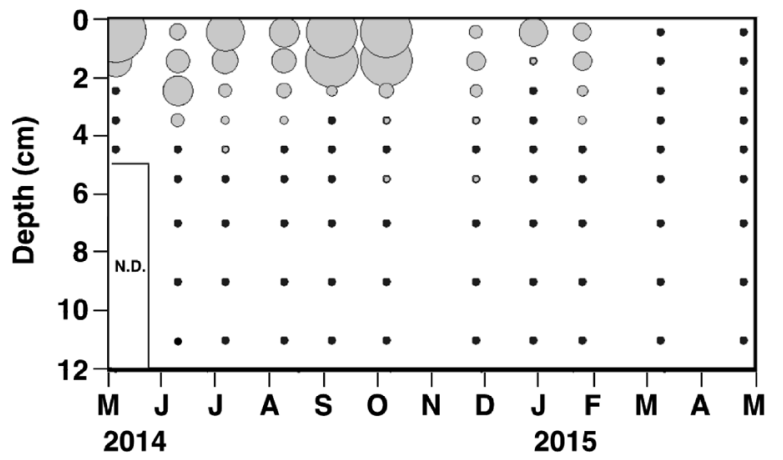

(b)
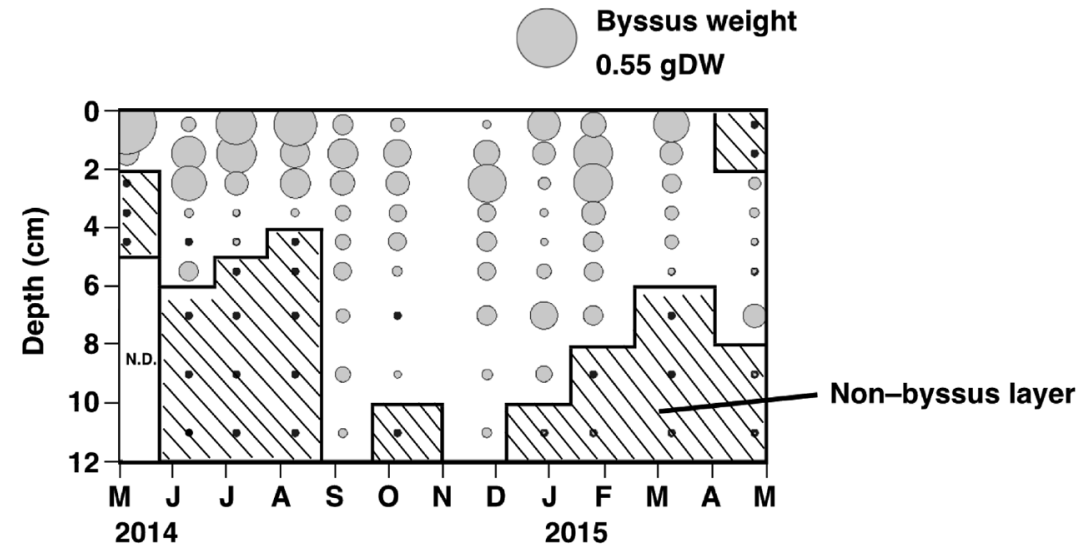

(c)

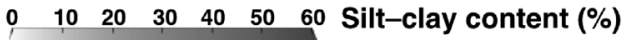

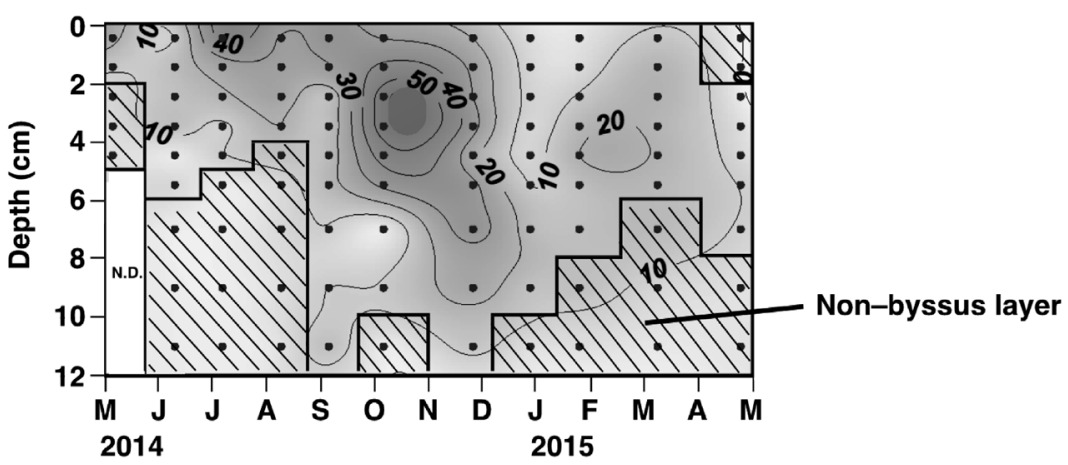

(d)

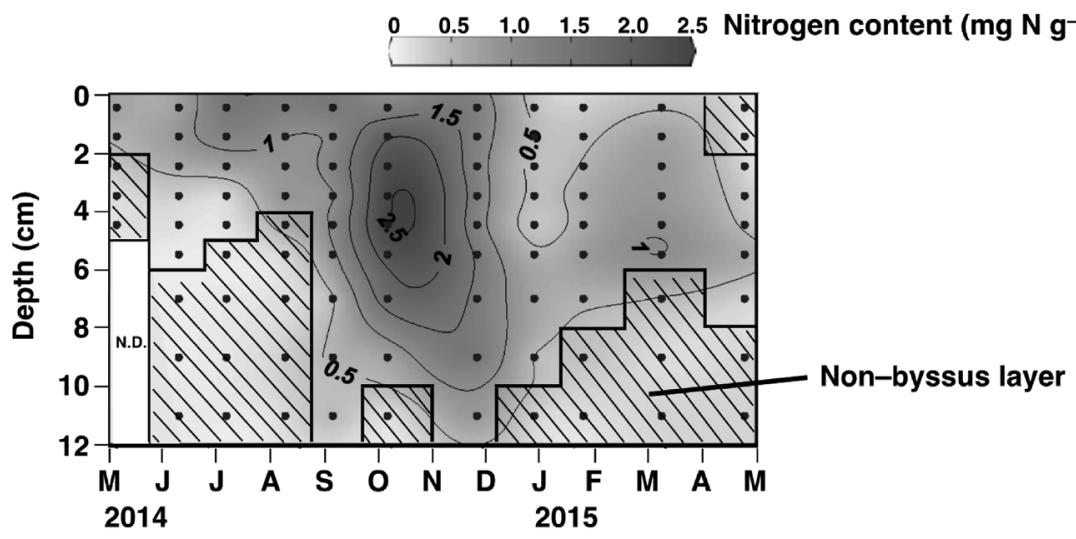

Fig. 5. Spatial and seasonal variations in (a) the number of Arcuatula senhousia in each layer $\left(45.3 \mathrm{~cm}^{3}\right)$, (b) byssus weight in each layer $\left(45.3 \mathrm{~cm}^{3}\right)$, (c) silt-clay content, and (d) nitrogen content to a depth of $12 \mathrm{~cm}$ at St. F. The black hatched area indicates the non-byssus layer. 


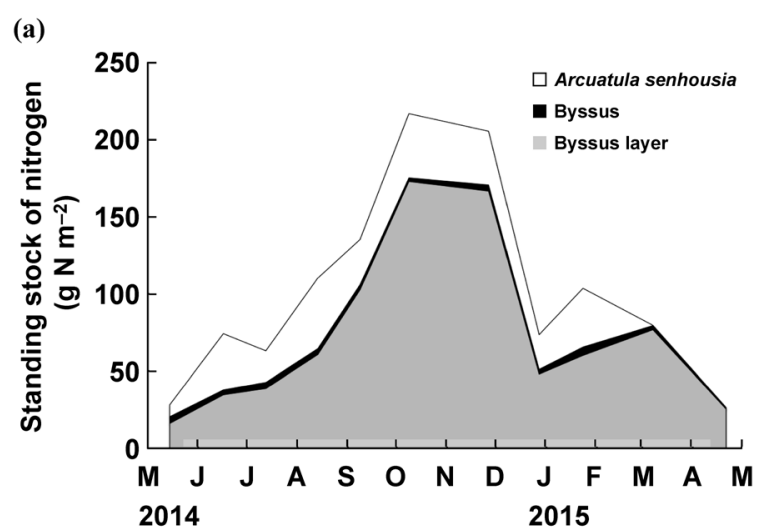

(b)

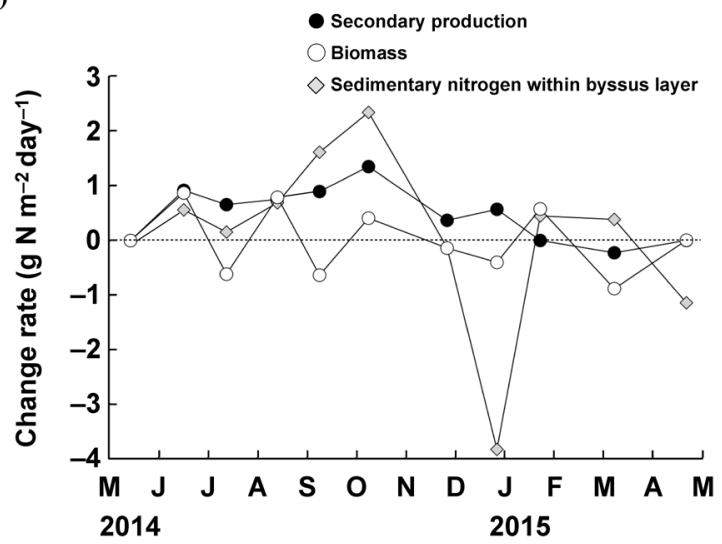

Fig. 6. Seasonal variation in the integrated standing stock of nitrogen. (a) White, black, and gray squares represent Arcuatula senhousia biomass, byssus, and sedimentary nitrogen, respectively, within the byssus layer. (b) Seasonal variation in the change rate of the integrated standing stock of nitrogen. Black circles, white circles, and gray diamonds represent secondary production of $A$. senhousia, biomass of $A$. senhousia, and sedimentary nitrogen, respectively, within the byssus layer.

Magni et al. (2000) have concluded that the excretion of A. senhousia and the short neck clam (Ruditapes philippinarum Adams \& Reeve) inhabiting the intertidal zone plays a major role in nutrient regeneration because it recycles inorganic forms of nitrogen and phosphorus that are available to primary producers. They have reported that the rate of ammonium excretion of $A$. senhousia is $1.3-$ $157.7 \mathrm{~g} \mathrm{NH}_{4}^{+} \mathrm{m}^{-2}$ year ${ }^{-1} \quad\left(0.2-24.0 \mathrm{mmol} \mathrm{NH}_{4}^{+} \mathrm{m}^{-2} \mathrm{~d}^{-1}\right)$ when their biomass is $36.5 \pm 24.5 \mathrm{gDW} \mathrm{m}^{-2}$ on a tidal flat in the Seto Inland Sea, Japan. Considering the weight-specific excretion rate of the mussels in this study $\left(205.0 \pm 148.6 \mathrm{gDW} \mathrm{m}^{-2}, \mathrm{DW} / \mathrm{WW}=8.6 \%\right)$, the excretion rate observed here reached $324.5 \mathrm{~g} \mathrm{NH}_{4}^{+} \mathrm{m}^{-2}$ year ${ }^{-1}$ (mean excretion rate, $10.0 \mu \mathrm{mol} \mathrm{NH}_{4}^{+} \mathrm{gDW}^{-1} \mathrm{~h}^{-1}$; Magni et al. 2000). The integrated standing stock of sedimentary nitrogen within the byssus layer during the growth period $\left(150.7 \mathrm{~g} \mathrm{~N} \mathrm{~m}^{-2} 7\right.$ months $\left.^{-1}\right)$ accounted for roughly half of the ammonium excreted by A. senhousia. Furthermore, sedimentary nitrogen within the byssus layer during the growth period was as high as the secondary production of A. senhousia in this study $\left(161.8 \mathrm{~g} \mathrm{~N} \mathrm{~m}^{-2}\right.$ year $\left.^{-1}\right)$.
Accumulated muddy sediments are swept away by tidal currents when A. senhousia die (Creese et al. 1997). In this study, the byssus-and the silt-clay content and nitrogen content within the byssus layer-decreased after the decline in A. senhousia biomass in December (Fig. 2). Further, the rate of change of $A$. senhousia biomass and sedimentary nitrogen within the byssus layer seemed to run out over a period of approximately 4 months [Fig. 6(b)]. The decrease in sedimentary nitrogen in the byssus layer may be related to the destruction of the mat due to strong winds that can reach $5.5 \mathrm{~cm} \mathrm{~s}^{-1}$ (average daily wind speed) during winter (December and January; Japan Meteorological Agency 2016).

On sandy tidal flats, the sediment surface is swept away by the flow of seawater and estuarine water, and the organic content in the sediment seems to be maintained at low levels. As A. senhousia begin to settle on the surface and grow throughout summer and fall, they accumulate sedimentary organic matter as the mat forms. As the $A$. senhousia abundance declines, the accumulated organic matter flows out along with their mat. Therefore, this study clearly indicates that the accumulation and release of organic matter within $A$. senhousia mats play major roles in nutrient cycling in the sandy tidal flats ecosystem, and that these mussels can change the equilibrium state of sandy tidal flats throughout their life cycle.

\section{Acknowledgements}

We would like to thank Mr. Takami Fujimori, Mr. Tsutomu Fukushima, and Mr. Jyo Tsuruta for piloting the boat. We also thank the students of the Laboratory of Marine Ecology, Prefectural University of Kumamoto, for their assistance with the fieldwork and chemical analysis in the laboratory. We would like to thank the editor Dr. Kojima and anonymous referees and English reviewers for their constructive comments on this manuscript.

\section{References}

Asmus H (1987) Secondary production of an intertidal mussel bed community related to its storage and turnover compartments. Mar Ecol Prog Ser 39: 251-266.

Ceccherelli VU, Rossi R (1984) Settlement, growth and production of the mussel Mytilus galloprovincialis. Mar Ecol Prog Ser 16: 173-184.

Creese R, Hooker S, de Luca S, Wharton Y (1997) Ecology and environmental impact of Musculista senhousia (Mollusca: Bivalvia: Mytilidae) in Tamaki Estuary, Auckland, New Zealand. New Zeal J Mar Fresh 31: 225-236.

Crooks JA (1998) Habitat alteration and community-level effects of an exotic mussel, Musculista senhousia. Mar Ecol Prog Ser 162: 137-152.

Dame RF (2011) Ecology of Marine Bivalves: An Ecosystem Approach, second edition. CRC press, United States of America, 283 pp. 
Grant WS (1977) High intertidal community organization on a rocky headland in Maine, USA. Mar Biol 44: 15-25.

Harger JRE (1970) The effect of wave impact on some aspects of the biology of sea mussels. Veliger 12: 401-414.

Haven DS, Morales-Alamo R (1972) Biodeposition as a factor in sedimentation of fine suspended solids in estuaries. Geol Soc America Mem 133: 121-130.

Hosozawa T, Kunii H, Nakamura M, Ojima T, Sugiyama Y, Yamaguchi K (2015) Temporal change in the spatial distribution of Asian bag mussel Arcuatula senhousia (Bivalvia, Mytilidae) population in Ohashi-River, Shimane Prefecture. Jpn J Benthol 70: 1-12. (in Japanese with English abstract)

Ishii R, Kawakami S, Sekiguchi H, Nakahara Y, Jinnai Y (2001) Larval recruitment of the mytilid Musculista senhousia in Ariake Sound, southern Japan. Venus 60: 37-55.

Ito N, Kajihara T (1981a) The ecological study of the mussel, Musculista senhousia, in Yokosuka harbor I distribution, population changes and total sulphide under the mussel nest. Marine Fouling 3: 37-41. (in Japanese)

Ito N, Kajihara T (1981b) The ecological study of the mussel, Musculista senhousia, in Yokosuka harbor II structures of byssal threads and nest. Marine Fouling 3: 43-46. (in Japanese)

Japan Meteorological Agency (2016) Various data, information. Available at: http://www.jma.go.jp/jma/menu/menureport.html (accessed on 1 May 2016)

Jones CG, Lawton JH, Shachak M (1994) Organisms as ecosystem engineers. Oikos 69: 373-386.

Jordan TE, Valiela I (1982) A nitrogen budget of the ribbed mussel, Geukensia demissa, and its significance in nitrogen flow in a New England salt marsh. Limnol Oceanogr 27: 75-90.

Kawaguchi O, Yamamoto T, Matsuda O, Hashimoto T (2004) Determination of the limiting nutrients for growth of nori laver and diatoms in Ariake Bay (Japan) by analyses of longterm variation in water quality. Oceanography in Jpn 13: 173183. (in Japanese with English abstract)

Lim HS, Park KY (1998) Population ecology of the mud mussel Musculista senhousia (Bivalvia: Mytilidae) on the mud tidal flat in Mokpo coastal area, southwest coast of Korea. 1. Distribution and growth. Korean J Malacol 14: 121-130. (in Korean with English abstract)

Magni P, Montani S, Takada C, Tsutsumi H (2000) Temporal scaling and relevance of bivalve nutrient excretion on a tidal flat of the Seto Inland Sea, Japan. Mar Ecol Prog Ser 198: 139-155.

Mistri M, Rossi R, Fano EA (2004) The spread of an alien bivalve (Musculista senhousia) in the Sacca di Goro Lagoon (Adriatic Sea, Italy). J Moll Stud 70: 257-261.

Miura T, Hirakiuchi H, Minamiura N, Nakamura M (2002) Shinji-ko, Nakaumi suisan shinkou taisaku kentou chousa jigyou -Hototogisu-gai kujyo taisaku chousa-[Marine promotion measure investigation business in Lake Shinji, Lake Nakaumi-Extermination measures investigation of Arcuatula senhousia-]. Business reports on experimental laboratory of inland water fishery in Shimane Prefectural Government for fiscal 2002: 78-81. (in Japanese)

Morton B (1974) Some aspects of the biology, population dynamics, and functional morphology of Musculista senhausia Benson (Bivalvia, Mytilidae). Pac Sci 28: 19-33.

Sousa R, Gutiérrez JL, Aldridge DC (2009) Non-indigenous invasive bivalves as ecosystem engineers. Biol Invasions 11: 2367-2385.

Takenaka R, Komorita T, Tsutsumi H (2016) Secondary production of the Asian mussel, Arcuatula (Musculista) senhousia, population in the Midori River tidal flats, Kyushu, Japan. Jpn J Benthol 71: 17-24. (in Japanese with English abstract)

Tsutsumi H, Takeguchi T, Maruyama A, Nakahara Y (2000) Seasonal fluctuations in the benthic community after the collapse of a clam, Ruditapes philippinarum, population on the Midori River tidal flats in Kumamoto. Jpn J Benthol 55: 1-8. (in Japanese with English abstract)

Tsutsumi H, Nomura R, Tanoue T, Komorita T, Iwasaki T, Fujimori $\mathrm{T}$ (2013) Influence of the development and destruction of muddy byssal mats made by a mytilid mussel, Musculista senhousia, on seasonal fluctuations of the macrobenthic community on sandy tidal flats. Jpn J Benthol 67: 47-55. (in Japanese with English abstract)

Yamaguchi H, Tsutsumi H, Tsukuda M, Nagata S, Kimura C, Yoshioka M, Shibanuma S, Montani S (2004) Utilization of photosynthetically produced organic particles by dense patches of suspension feeding bivalves on the sand flat of Midori River estuary, Kyushu, Japan. Benthos Res 59: 67-77. 